\title{
Corynebacterium freiburgense sp. nov., isolated from a wound obtained from a dog bite
}

\author{
Correspondence \\ Guido Funke \\ Idg.funke@t-online.de
}

\author{
Guido Funke, ${ }^{1}$ Reinhard Frodl, ${ }^{1}$ Kathryn A. Bernard ${ }^{2}$ and Ralf Englert ${ }^{3}$ \\ ${ }^{1}$ Department of Medical Microbiology and Hygiene, Gärtner and Colleagues Laboratories, \\ Elisabethenstrasse 11, 88212 Ravensburg, Germany \\ ${ }^{2}$ National Microbiology Laboratory, Public Health Agency of Canada, 1015 Arlington Avenue, \\ Winnipeg, MB R3E 3R2, Canada \\ ${ }^{3}$ Department of Medical Microbiology, Labor Clotten, Bismarckallee 10, 79098 Freiburg/Breisgau, \\ Germany
}

\begin{abstract}
A non-lipophilic, coryneform bacterium, isolated from a patient's wound obtained from a dog bite, was characterized by phenotypic, chemotaxonomic and molecular genetic methods.

Chemotaxonomic features suggested assignment of the unknown bacterium to the genus

Corynebacterium. The isolate exhibited the following peculiar features which made it possible to differentiate it phenotypically from all other medically relevant corynebacteria: older colonies exhibited a 'spoke-wheel' macroscopic morphology, colonies were strongly adherent to blood agar and the strain did not have pyrazinamidase activity, but was positive for $\beta$-galactosidase. $16 \mathrm{~S}$ rRNA gene sequencing showed that the closest phylogenetic relative exhibited more than $3.9 \%$ divergence from the unknown isolate. Based on phenotypic and molecular genetic data, it is proposed that the isolate should be classified as a representative of a novel species, Corynebacterium freiburgense sp. nov., with strain $1045^{\top}\left(=\right.$ CCUG $56874^{\top}=$ DSM $\left.45254^{\top}\right)$ as the type strain.
\end{abstract}

During the 1990s, a plethora of novel Corynebacterium species isolated from human clinical specimens was described (Funke \& Bernard, 2007). Within the last few years, microbiologists have also focused on descriptions of novel Corynebacterium species obtained from animals (Collins et al., 1999b, 2001, 2004; Fernández-Garayzábal et al., 2004). Although it is generally agreed that the most frequently found Corynebacterium species in human clinical materials have already been defined, novel Corynebacterium species are still being described, often based, however, on single strains (Yassin et al., 2002; Yassin, 2007). The present report outlines the characteristics of a single, unusual Corynebacterium strain $\left(1045^{\mathrm{T}}\right)$ which may have been transmitted from an animal to a human. Using a polyphasic taxonomic approach, it has been demonstrated that this strain represents another novel Corynebacterium species.

Strain $1045^{\mathrm{T}}$ was cultured in August 2008 from a wound swab of a 57-year-old female who had been bitten by her dog on her forearm. Strain $1045^{\mathrm{T}}$ grew together with Pasteurella multocida, $\alpha$-haemolytic streptococci and Prevotella species.

Gram staining of cells of strain $1045^{\mathrm{T}}$ showed coryneform bacteria arranged singly with typical club-shaped elements;

The GenBank/EMBL/DDBJ accession number for the 16S rRNA gene sequence of strain $1045^{\top}$ is FJ157329. filamentous forms were not observed. The isolate was negative for partial acid-fastness. Colonies on Columbia sheep blood agar plates (BD) were beige-whitish, showed irregular margins and were $1-2 \mathrm{~mm}$ in diameter. Supplementation of Columbia sheep blood agar plates with Tween 80 (Merck) (Funke \& Bernard, 2007) did not enhance colony size significantly, i.e. strain $1045^{\mathrm{T}}$ was nonlipophilic. Interestingly, the colonies were strongly adherent to blood agar; of the coryneform bacteria, adherence to agar is also observed in some strains of Corynebacterium durum (Riegel et al., 1997), Corynebacterium sundsvallense (Collins et al., 1999a) and Corynebacterium thomssenii (Zimmermann et al., 1998). Another very peculiar feature was the 'spoke-wheel' macroscopic morphology of the colonies after 5 days of incubation at $37{ }^{\circ} \mathrm{C}$ in a $5 \% \mathrm{CO}_{2^{-}}$ enriched atmosphere. This type of morphology is not seen in other true corynebacteria, but may be observed in some Rothia dentocariosa strains (Funke \& Bernard, 2007).

Strain $1045^{\mathrm{T}}$ was further screened for chemotaxonomic features and biochemical reactions using previously described methods (Funke et al., 1993). Chemotaxonomic investigations revealed the presence of mesodiaminopimelic acid as diamino acid of the peptidoglycan, as well as mycolic acids, features which, together with the negative reaction for partial acid-fastness, are compatible with the assignment of strain $1045^{\mathrm{T}}$ to the genus 
Corynebacterium (Funke \& Bernard, 2007). The main straight-chain saturated fatty acids were palmitic and stearic acids; oleic acid was the predominant unsaturated fatty acid.

When applying the commercial API Coryne (bioMérieux), a negative pyrazinamidase reaction was observed (numerical API Coryne code: 1440365), which prompted us to consider that the isolate belonged to the Corynebacterium diphtheriae/C. ulcerans/C. pseudotuberculosis group of bacteria, since these bacteria are the only known largecolony-forming, medically relevant corynebacteria that do not express this particular enzyme continuously (Funke \& Bernard, 2007). As a result of this and because of the clinical nature of the patient's wound, the isolate was tested for the presence of the diphtheria toxin gene using PCR primers Cdipht-1 (5'-ATCCACTTTTAGTGCGAGAACC TTGGTCA) and Cdipht-2 (5'-GAAAACTTTTCTTCG TACCACGGGACTAA), as outlined previously (Nakao \& Popovic, 1997). Results showed that strain $1045^{\mathrm{T}}$ did not harbour this virulence gene.

Another unusual feature for a medically relevant corynebacterium was the positive $\beta$-galactosidase reaction of strain $1045^{\mathrm{T}}$ in both the API Coryne (at pH 7.4) and the API ZYM (at pH 5.4) (bioMérieux) systems. C. durum (Rassoulian Barrett et al., 2001) and Corynebacterium glucuronolyticum (Funke et al., 1995) are the only other clinically significant true corynebacteria that express this enzyme. Two further features of strain $1045^{\mathrm{T}}$ are also not observed frequently in other clinical corynebacteria (Funke \& Bernard, 2007), i.e. a positive aesculinase reaction (delayed, turning positive after $72 \mathrm{~h}$ incubation only) and the ability to ferment lactose [tested with both the API Coryne and the API 50CH (bioMérieux) systems].

In summary, strain $1045^{\mathrm{T}}$ exhibited some very unusual phenotypic features that are not compatible with any Corynebacterium species with validly published names. Therefore, the phylogenetic distinctiveness of strain $1045^{\mathrm{T}}$ was investigated by sequencing the almost-entire $16 \mathrm{~S}$ rRNA gene (1481 bp) according to a published method (Beck et al., 2008). Strain $1045^{\mathrm{T}}$ clustered with the type strains of the 70 currently recognized species of the genus Corynebacterium and 16S rRNA gene sequence similarities ranged from $91.54 \%$ with $C$. durum to $96.06 \%$ with $C$. pseudotuberculosis. The ten closest phylogenetic relatives of the isolate were the type strains of C. pseudotuberculosis (96.06\% 16S rRNA gene sequence similarity), Corynebacterium vitaeruminis (95.92\%), C. ulcerans (95.82\%), Corynebacterium felinum (95.81\%), Corynebacterium spheniscorum (95.60\%), Corynebacterium argentoratense (95.57\%), Corynebacterium variabile (95.57\%), Corynebacterium aquilae (95.55\%), C. diphtheriae (95.34\%) and Corynebacterium falsenii (95.19\%). As expected, the type strains of members of the genera Dietzia, Rhodococcus and Tsukamurella were also related phylogenetically to the isolate, with $16 \mathrm{~S}$ rRNA gene sequence similarities of approximately $92 \%$. It is evident from the molecular genetic data, which clearly shows $16 \mathrm{~S}$ rRNA gene sequence divergence above the $3 \%$ threshold (Stackebrandt \& Goebel, 1994), that strain $1045^{\mathrm{T}}$ represents a novel Corynebacterium species. Table 1 outlines phenotypic features that enable the isolate to be differentiated clearly from its nearest phylogenetic relatives. A phylogenetic tree was constructed using the neighbour-joining method included in the MEGA4 software suite (Tamura et al., 2007), based on a comparison of approximately $1350 \mathrm{nt}$. Bootstrap values, expressed as percentages of 1000 replications, are given at each branching point in Fig. 1. From the treeing analysis, it is evident that strain $1045^{T}$ represents a distinct Corynebacterium species.

Antimicrobial susceptibility testing was performed using the microdilution method of the Clinical and Laboratory Standards Institute (CLSI), as well as the interpretation guidelines of this organization (CLSI, 2006). Strain $1045^{\mathrm{T}}$ was susceptible to cefotaxime, ciprofloxacin, doxycycline, erythromycin, gentamicin, linezolid, meropenem, penicillin, rifampicin and vancomycin. The strain was also susceptible to the vibriocidal compound O/129 (Funke et al., 1996).

It is interesting to note that, among the Corynebacterium species, only a few species, e.g. Corynebacterium auriscanis (Collins et al., 1999b) and C. ulcerans (Lartigue et al., 2005), have so far been isolated from dogs. However, in our experience, it is not unlikely that many other Corynebacterium species (and even some novel species) might be detected in clinical materials from dogs if samples are screened more systematically for the presence of corynebacteria.

Based on the results of the outlined polyphasic taxonomic study, it is proposed that strain $1045^{\mathrm{T}}$ represents a novel species of the genus Corynebacterium, Corynebacterium freiburgense sp. nov.

Table 1. Characteristics that differentiate strain $1045^{\top}$ from its nearest phylogenetic relatives

Species: 1, C. freiburgense sp. nov. (strain $1045^{\mathrm{T}}$ ); 2, C. felinum; 3, C. pseudotuberculosis; 4, C. ulcerans; 5, C. vitaeruminis. +, Positive; -, negative; V, variable; ND, no data. Data from this study, Collins et al. (2001) and Funke \& Bernard (2007).

\begin{tabular}{|c|c|c|c|c|c|}
\hline Characteristic & 1 & 2 & 3 & 4 & 5 \\
\hline Pyrazinamidase & - & + & - & - & + \\
\hline Nitrate reductase & + & - & - & - & + \\
\hline Urease & - & - & + & + & + \\
\hline Pyrrolidonyl arylamidase & - & + & - & - & + \\
\hline$\alpha$-Glucosidase & - & + & $\mathrm{v}$ & + & ND \\
\hline$\beta$-Glucosidase & + & - & - & - & + \\
\hline$\beta$-Galactosidase & + & - & - & - & ND \\
\hline Acid production from lactose & + & - & - & - & - \\
\hline
\end{tabular}




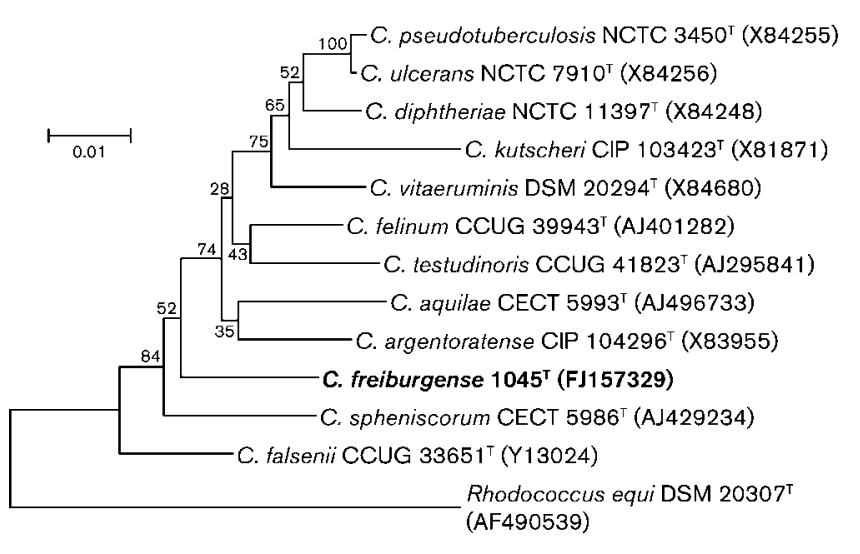

Fig. 1. Phylogenetic tree based on $16 \mathrm{~S}$ rRNA gene sequences showing the position of strain $1045^{\top}$ in relation to the type strains of its closest phylogenetic neighbours; corresponding GenBank sequence accession numbers are given. The sequence of Rhodococcus equi DSM $20307^{\top}$ was used as an outgroup. Bar, 0.01 nucleotide substitutions per site. Bootstrap values, expressed as percentages of 1000 replications, are given at branching points.

\section{Description of Corynebacterium freiburgense sp. nov.}

Corynebacterium freiburgense (frei.bur.gen'se. N.L. neut. adj. freiburgense from Freiburg/Breisgau, Germany, named after the city where the bacterium was first isolated).

Cells stain Gram-positive and are non-spore-forming and non-motile. They are typically club-shaped rods that occur as single cells, in pairs or in small clusters. Colonies are beige-whitish, dryish, convoluted with irregular edges, strongly adherent to sheep blood agar plates and up to 1$2 \mathrm{~mm}$ in diameter after $48 \mathrm{~h}$ incubation. In 5-day-old colonies, a 'spoke-wheel' macroscopic morphology may be observed. Weak anaerobic growth is observed. Catalasepositive. Acid is produced from fructose, galactose, glucose, 5-ketogluconate, lactose, maltose, mannose, ribose, sucrose and tagatose, but not from $\mathrm{N}$-acetylglucosamine, adonitol, amygdalin, arabinose, arabitol, arbutin, cellobiose, dulcitol, erythritol, fucose, gentiobiose, gluconate, glycerol, inositol, inulin, 2-ketogluconate, lyxose, mannitol, melezitose, melibiose, methyl $\alpha$-D-glucoside, methyl $\alpha$-D-mannoside, methyl $\beta$-xyloside, raffinose, rhamnose, salicin, sorbitol, sorbose, starch, trehalose, turanose, xylitol or xylose. The following enzyme activities can be detected: nitrate reductase, $\beta$-galactosidase, $\beta$-glucosidase, esterase (C4), esterase lipase (C8), leucine arylamidase, cystine arylamidase, acid phosphatase and phosphoamidase. Pyrazinamidase, urease, pyrrolidonyl arylamidase, gelatinase, lipase, valine arylamidase, trypsin, chymotrypsin, $\alpha-$ galactosidase, $\beta$-glucuronidase, $\alpha$-glucosidase, $N$-acetyl- $\beta$ glucosaminidase, $\alpha$-mannosidase and $\alpha$-fucosidase activities are not detected. The CAMP (Christie-AtkinsMunch-Petersen) reaction is negative. The cell wall contains meso-diaminopimelic acid and mycolic acids are also present. The main straight-chain saturated fatty acids are palmitic and stearic acids; oleic acid is the predominant unsaturated fatty acid.

The type strain is $1045^{\mathrm{T}}$ (=CCUG $56874^{\mathrm{T}}=$ DSM $45254^{\mathrm{T}}$ ), isolated from a patient's wound obtained from a dog bite.

\section{Acknowledgements}

We thank Leyla Kaya for expert technical assistance.

\section{References}

Beck, M., Frodl, R. \& Funke, G. (2008). Comprehensive study of strains previously designated Streptococcus bovis consecutively isolated from human blood cultures and emended description of Streptococcus gallolyticus and Streptococcus infantarius subsp. coli. J Clin Microbiol 46, 2966-2972.

CLSI (2006). Methods for antimicrobial dilution and disk susceptibility testing of infrequently isolated or fastidious bacteria, document M45-A. Wayne, PA: Clinical and Laboratory Standards Institute.

Collins, M. D., Bernard, K. A., Hutson, R. A., Sjödén, B., Nyberg, A. \& Falsen, E. (1999a). Corynebacterium sundsvallense sp. nov., from human clinical specimens. Int J Syst Bacteriol 49, 361-366.

Collins, M. D., Hoyles, L., Lawson, P. A., Falsen, E., Robson, R. L. \& Foster, G. (1999b). Phenotypic and phylogenetic characterization of a new Corynebacterium species from dogs: description of Corynebacterium auriscanis sp. nov. J Clin Microbiol 37, 3443-3447.

Collins, M. D., Hoyles, L., Hutson, R. A., Foster, G. \& Falsen, E. (2001). Corynebacterium testudinoris sp. nov., from a tortoise, and Corynebacterium felinum sp. nov., from a Scottish wild cat. Int J Syst Evol Microbiol 51, 1349-1352.

Collins, M. D., Hoyles, L., Foster, G. \& Falsen, E. (2004). Corynebacterium caspium sp. nov., from a Caspian seal (Phoca caspica). Int J Syst Evol Microbiol 54, 925-928.

Fernández-Garayzábal, J. F., Vela, A. I., Egido, R., Hutson, R. A., Lanzarot, M. P., Fernández-García, M. \& Collins, M. D. (2004). Corynebacterium ciconiae sp. nov., isolated from the trachea of black storks (Ciconia nigra). Int J Syst Evol Microbiol 54, 2191-2195.

Funke, G. \& Bernard, K. A. (2007). Coryneform gram-positive rods. In Manual of Clinical Microbiology, 9th edn, pp. 485-514. Edited by P. R. Murray, E. J. Baron, J. H. Jorgensen, M. L. Landry \& M. A. Pfaller. Washington, DC: American Society for Microbiology.

Funke, G., Martinetti Lucchini, G., Pfyffer, G. E., Marchiani, M. \& von Graevenitz, A. (1993). Characteristics of CDC group 1 and group 1like coryneform bacteria isolated from clinical specimens. J Clin Microbiol 31, 2907-2912.

Funke, G., Bernard, K. A., Bucher, C., Pfyffer, G. E. \& Collins, M. D. (1995). Corynebacterium glucuronolyticum sp. nov. isolated from male patients with genitourinary infections. Med Microbiol Lett 4, 204-215.

Funke, G., Lawson, P. A., Bernard, K. A. \& Collins, M. D. (1996). Most Corynebacterium xerosis strains identified in the routine clinical laboratory correspond to Corynebacterium amycolatum. J Clin Microbiol 34, 1124-1128.

Lartigue, M.-F., Monnet, X., Le Flèche, A., Grimont, P. A. D., Benet, J.-J., Durrbach, A., Fabre, M. \& Nordmann, P. (2005). Corynebacterium ulcerans in an immunocompromised patient with diphtheria and her dog. J Clin Microbiol 43, 999-1001. 
Nakao, H. \& Popovic, T. (1997). Development of a direct PCR assay for detection of the diphtheria toxin gene. J Clin Microbiol 35, 1651-1655.

Rassoulian Barrett, S. L., Cookson, B. T., Carlson, L. C., Bernard, K. A. \& Coyle, M. B. (2001). Diversity within reference strains of Corynebacterium matruchotii includes Corynebacterium durum and a novel organism. J Clin Microbiol 39, 943-948.

Riegel, P., Heller, R., Prevost, G., Jehl, F. \& Monteil, H. (1997). Corynebacterium durum sp. nov., from human clinical specimens. Int J Syst Bacteriol 47, 1107-1111.

Stackebrandt, E. \& Goebel, B. M. (1994). Taxonomic note: a place for DNA-DNA reassociation and $16 \mathrm{~S}$ rRNA sequence analysis in the present species definition in bacteriology. Int J Syst Bacteriol 44, 846-849.
Tamura, K., Dudley, J., Nei, M. \& Kumar, S. (2007). MEGA4: molecular evolutionary genetics analysis (MEGA) software version 4.0. Mol Biol Evol 24, 1596-1599.

Yassin, A. F. (2007). Corynebacterium ureicelerivorans sp. nov., a lipophilic bacterium isolated from blood culture. Int J Syst Evol Microbiol 57, 1200-1203.

Yassin, A. F., Steiner, U. \& Ludwig, W. (2002). Corynebacterium appendicis sp. nov. Int J Syst Evol Microbiol 52, 1165-1169.

Zimmermann, O., Spröer, C., Kroppenstedt, R. M., Fuchs, E., Köchel, H. G. \& Funke, G. (1998). Corynebacterium thomssenii sp. nov., a Corynebacterium with $N$-acetyl- $\beta$-glucosaminidase activity from human clinical specimens. Int J Syst Bacteriol 48, 489-494. 